\title{
RELIGIOUS PLURALISM DISCOURSE IN PUBLIC SPHERE OF INDONESIA: A Critical Application of Communicative Action Theory to Inter-Religious Dialogue
}

\author{
Sung-Min Kim \\ Indonesian Consortium for Religious Studies (ICRS), Yogyakarta, \\ Indonesia \\ E-mail: suminto@gmail.com \\ J. B. Banawiratma \\ Duta Wacana Christian University, Indonesia \\ E-mail: banawiratma@staff.ukdw.ac.id \\ Dicky Sofjan \\ Inter-Religious Studies, Gadjah Mada University, Yogyakarta, \\ Indonesia \\ E-mail: dickysofjan@ugm.ac.id
}

\begin{abstract}
This paper examines religious pluralism discourse in postReformasi Indonesia. Though there is general consensus about the importance of maintaining inter-religious harmony, there are still various perspectives and arguments on the idealization of dealing with religious diversity in society. The differences are found not only between the advocates and opponents of religious pluralism but also among proponent groups of religious pluralism. This paper looks at how religious organizations for inter-religious harmony struggle for legitimating their religious pluralism ideals in society. In this context, this paper, by using Habermas' theory of communicative action, focuses on the characteristics of their efforts to communicate with others in the public sphere. It examines inter-faith dialogue done by NGOs' activities and arguments, focusing on their validity claims for justifying religious pluralism. This paper argues that some conceptions and presuppositions of this theory need to be critically assessed and modified in analyzing these NGOs' discourse so that it can be appropriately applied to the Indonesian context in which religion has substantial power to influence people's thoughts and behaviors. Particularly it will point out 1) the problem of universalized rationality, 2) power relation and strategic action, and 3) the role of religious reason in public discourse.
\end{abstract}

Keywords: Religion; Islamic ideology; local belief; social laboratory; social harmony. 
Article history: Received: 11 July 2020; Revised: 01 August 2020; Accapted: 19 August 2020; Available online: 01 September 2020.

\section{How to cite this article:}

Min Kim, Sung, J.B. Banawiratma, and Dicky Sofjan. "Religious Pluralism Discourse in Public Sphere of Indonesia: A Critical Application of Communicative Action Theory to Inter-Religious Dialogue". Religio: Jurnal Studi Agama-agama 10, no. 2 (2020): 158-188. https://doi.org/10.15642/religio.v10i2.1307

\section{Introduction}

Indonesia has a very unique history of inter-religious relation. At various stages of history major religions of the world such as Buddhism, Hinduism, Islam and Christianity flourished in this archipelago, mixing and mingling with indigenous beliefs, and eventually created their own syncretic religious traditions. Like other countries, there have been many competitions and conflicts among those religions. Conquest through wars in the time of changing power of kingdoms in the region based on religious beliefs, proselytizing local people with imperial power, and the process of compromising major religions doctrines, rituals and symbols with local beliefs also take the landscape of inter-religious relations in Indonesia. Going through such long interactions between religions, Indonesians have developed local wisdom about tolerance toward people of different background in religion, language and culture.

Such tradition of tolerance is shown in many aspects of Indonesian society. Republic of Indonesia was established on the foundation of Pancasila, by which religious freedom is guaranteed in the principle of belief in One Deity (Ketuhanan yang Maha Esa) so that it could embrace all the people of various religious backgrounds, encouraging people's religious life. This is unlike with many other Muslim majority countries which take Sharia as the constitutional base. Indonesian Muslims who take over $85 \%$ of the population mostly have tolerant attitudes towards other faiths, living peacefully in religious diverse communities. Whenever there are brutal conflicts between religious groups or terrorists attacks, leaders of major Islamic organizations such as Nabdlatul Ulama (NU) and Mubammadiyah have voiced their condemnation and many other religious or inter-religious groups have shown strong solidarity against act of terrorism. Even in the New Order regime, stable inter-religious relation was primary 
concern for economic development and for maintaining political power and national unity. Suharto frequently suppressed the political influence of major religions and banned so-called SARA discourse referring to Suku, Agama, Ras dan Antar Golongan (ethnicity, religion, race and social classes) in public place.

However, there have also been many conflicts related to religion and often been major social problems causing social unrest and the destruction of social unity. During the early period of Reformasi Era religious tensions flared up in various regions across Indonesia, including Maluku, Poso and Java. These took the form of violent, often brutal conflicts, riots or acts of terrorism. They may have been caused by decentralization, political liberalization, power struggles between the police and the army, local elite maneuvering, and even the intervention of international terrorist networks. ${ }^{1}$ In most cases religious identity has been widely used as a tool to mobilize people and escalate hostility between conflicting groups. Religious appeals are perhaps the easiest and most efficient means to strengthen communal loyalties and provoke violent conflicts. ${ }^{2}$

Indonesians managed to develop the value of pluralism and consolidate democracy despite unfriendly circumstances. If we focus only on terrorism activities, discrimination against minority religious groups, and demonstrations by extremist groups we may think Indonesia is in a severe crisis of inter-religious conflicts. However, from the long-term perspective, and considering complex interreligious history and current circumstances, it should be highly appreciated that Indonesia has maintained religious diversity and religious freedom relatively successful compared to other newly democratized countries or Muslim majority countries. Indonesians still regard the Pancasila to be the best option for a pluralistic

\footnotetext{
1 Jacques Bertrand, Nationalism and Ethnic Conflict in Indonesia (Cambridge; New York: Cambridge University Press, 2004), 109; Clinton Fernandes and Damien Kingsbury, "Terrorism in Archipelagic Southeast Asia," in Violence in between: Conflict and Security in Archipelagic Southeast Asia, ed. Damien Kingsbury, Monash Papers on Southeast Asia 62 (Victoria and Singapore: Monash University Press and ISEAS Publications, 2005), 12-32.

2 Mujīburraḥmān, Feeling Threatened: Muslim-Christian Relations in Indonesia's New Order (Amsterdam: Amsterdam University Press, 2006); Alexander R. Arifianto, "Explaining the Cause of Muslim-Christian Conflicts in Indonesia: Tracing the Origins of Kristenisasi and Islamisasi," Islam and Christian-Muslim Relations 20, no. 1 (2009): 73-89.
} 
Indonesia and inter-religious harmony and tolerance are integral parts of Indonesian society. ${ }^{3}$

Moreover, these developments have been achieved despite slower democratic progress in the government sector, such as increased corruption, inefficient bureaucracy, lack of legal and institutional coordination and weak and sometimes unfair law enforcement coordinating inter-religious disputes. This is also significant in that has been initiated by civil society sector which voluntarily mediated conflicting groups and led inter-religious dialogue and cooperation. Many NGOs' contributed to prevent conflicts or to initiate reconciliation and to create a social environment of peaceful coexistence since 1990s, when the government lost controlling power to handle with simmering conflicts. Indonesians enjoy much higher freedom of religion than those in Arab Islamic states. Compared even to "secular" democratic countries in the West where Muslim immigrants and existing citizens often in troubles due to religious and cultural differences, Indonesia's ability of civil society to dealing with religious diversity is worthy to be praised.

Nonetheless, in dealing with religious diversity Indonesia is facing new challenges as democracy is being consolidated and globalization is penetrating into Indonesians' everyday life. First, democratized society opened up broader opportunity for people to express their thought, beliefs and political will and so on. In a society where people's diverse interests are expressed freely, conflicts occur more frequently than in an authoritarian society. Indonesia is not an exception. With the development of Information and Communication Technology, the range of communication between individuals and groups has been expanded, and the Internet space has become an opportunity to overcome the limitations of existing political structures and to open new forms of public sphere, in which citizens can express their political aspirations. Thanks to Social Media, people enjoy far broader freedom in communicating with others than in the past. The amount of information that can be acquired cannot

3 CRCS, Laporan Tabunan Kebidupan Beragama Di Indonesia Tabun 2008 (Yogyakarta: Center for Religious and Cross-cultural Studies, 2008), 6-7; Jeremy Menchik, Islam and Democracy in Indonesia: Tolerance without Liberalism (Cambridge: Cambridge University Press, 2016). 
be compared with the past, and now it is difficult for the government to control the speed and the scope of information.

Globalization has made somewhat universalized culture and values. Globalized capitalism is the most penetrating power, whether we like it or not, that influences people's mind and lifestyles and global cultures are assimilated in locality. Democracy, tolerance, and human rights are regarded as universal values and accordingly, people tend to think how they accommodate such values in their everyday life, religious beliefs and in public domain. This trend is also applied to Indonesian Muslims. Broader opportunity to discuss, debate and contest on religious issues in relatively autonomous and globalized public sphere has made them rethink about the way of achieving Islamic ideals in the society, the way of expressing their piety according to the transformative social changes, and relating themselves to people of different faiths and so on. In a globalized situation, "Islam is presented in a way that is sophisticated, fresh, and hybrid, in order to make it an appealing alternative to urban, capitalist cultures." ${ }^{4}$

Noorhaidi Hasan diagnoses this trend as "Post-Islamism in Indonesia" which is represented by urban middle class Muslims who prefer to actualize Sharia from the below than to follow militant extremism. They are largely tolerant and believe that Islamic values are not contradictory to democracy. ${ }^{5}$ On the other hand, it is also true that the increase of religious intolerance presented as collective violence to minority religious groups, acts of terror, hate speech and fake news is part of world-wide phenomenon. ${ }^{6}$ The spread of fundamentalism propaganda through Web sites, hate speech and fake news through social media like WhatsApp and Instagram is so quick and the impact of it is powerful. This is also a global trend which has similar impact on Indonesian society. What is noteworthy in this trend is that the reasons to be intolerant are justified by the messages that are spreading out. It becomes severe threat to the culture of tolerance that Indonesians have proudly developed in their long history and divide society according to narrow interpretation of

4 Noorhaidi Hasan, "Post-Islamist Politics in Indonesia," in Post-Islamism:The Changing Faces of Political Islam, ed. Asef Bayat (New York: Oxford University Press, 2013), 159.

${ }^{5}$ Hasan, "Post-Islamist Politics in Indonesia."

${ }^{6}$ Bernard Adeney-Risakotta, Living in a Sacred Cosmos: Indonesia and the Future of Islam (New Haven, CT: Yale Univ Southeast Asia Studies, 2018), 277-81. 
religious dogma and produce biased hostility toward religious others. This is a kind of negative discourse that counters right meaning of religious pluralism. Fake news and hate speech implicitly legitimize intolerance and sometimes justify using violence against religious others, threatening solidarity between religious groups.

In a democratized and globalized society, the government is no longer able to suppress such discourse as they did during the authoritarian regime with the policy of SARA, or implement unilateral inter-religious harmony program. Now is the time that social consensus on the way and system of accepting diversity and social consciousness that fit the social environment should be formed through discussion and debate. What is needed for the maturation of this social consensus is the deliberation in the public sphere. Deliberation is an important measure of democratic consolidation. Citizens are more actively involved in politics through their experience in sharing necessary information, expressing their opinions in the public sphere, discussing about common good for the society, and incorporating them into national policies.

It has significance in the formation of deliberative democracy in the sense that they have brought both religiously and politically sensitive issues into the public sphere and have made critical voices toward the civil society and the government for seeking wider tolerance and freedom of religion for religiously marginalized individuals and groups. In this context, it is worthy of examining civil efforts that have been influencing the change of the notion of religious pluralism in Indonesian society. As stated above, NGOs' activities for inter-religious dialogue and cooperation have not remained in just normalizing inter-religious relations but seek to challenge conventional notion of religious pluralism in the society, and to change it as a democratic value which goes beyond particular religion's theological debate or a contested political interest but embrace all the members of society and consolidate national solidarity based on the value.

\section{Conceptualizing Religious Pluralism Discourse}

1. Theological Perspective: Christian and Islamic Theology of Religious Pluralism

In Christian theology of religious pluralism, it is mainly in search for salvation outside of Christianity. It is theological attempts 
to discover how Christians could recognize, understand and evaluate other faiths. Pluralist theologians commonly argue that Christians should not "regard their own religion as the one and only 'true' faith and way of 'salvation' uniquely superior to all others."” For them, God's revelation is not limited to Christianity but God has spoken to other religions as well. They contend that the whole truth about God is beyond human comprehension and our efforts to seek these truths can never be complete. In order to understand "truth" more profoundly and completely it is obligatory to enter into conversation with other religions. ${ }^{8}$ Hick suggests more elaborate grounds for pluralism, hypothesizing that there is one divine Reality that exists beyond the scope of human comprehension. ${ }^{9}$ What we know about this Reality, he contends, is what is perceived and experienced by each individual in a particular tradition. In effect, each religious tradition, civilization and individual preference acts as a conceptual lens through which people recognize "the Real." Thus, there is some disparity between the Real itself and the Real as it appears to the human conscience. Diana L. Eck's conception is also useful in understanding theological discussion regarding religious pluralism. She distinguishes pluralism from tolerance, relativism, and syncretism. According to her, pluralism is an active attitude toward the seeking of understanding (other religious truths), assumes real commitment based on respect for differences, and achieved through inter-religious dialogue. ${ }^{10}$

It is necessary to compare pluralist Muslim intellectuals with Christian theology of religious pluralism. Conventional way of interpreting the Quran is textualist tradition, which understands the text of the Quran literally and apply the contents of the text directly into religious rituals, relation to others and even laws and regulations without considering the original circumstances when the text was

\footnotetext{
7 Paul F. Knitter, "Introduction," in The Myth of Religious Superiority: Multi-Faith Explorations of Religious Pluralism, ed. Paul F. Knitter (New York: Orbis Books, 2005), viii.

8 Paul F. Knitter, "Is the Pluralist Model a Western Imposition?: A Response in Five Voices," in The Myth of Religious Superiority: Multi-Faith Explorations of Religious Pluralism, ed. Paul F. Knitter (New York: Orbis Books, 2005), 33-35.

9 John Hick, An Interpretation of Religion: Human Responses to the Transcendent (New Haven: Yale University Press, 1989), 242.

${ }^{10}$ Diana L. Eck, "Is Our God Listening? Exclusivism, Inclusivism, and Pluralism," in Islam and Global Dialogue: Religious Pluralism and the Pursuit of Peace, ed. Roger Boase (Hants and Burlington: Ashgate, 2005), 40-47.
} 
written. Historically long most Muslim Intellectuals had held rigid, literal tradition of interpretation to the Quran and Sunnah of the Prophet. As Ibn Manzur defines the Quran as "the inimitable revelation, the Speech of God revealed to the Prophet Muhammad through the Angel Gabriel [existing today] literally and orally in the exact wording of the purest Arabic," 11 the majority of Muslim scholars believed that the Quran is Allah's revelation and thus has universal values and practical guidance to Muslims regardless of cultural, socio-economic change.

By contrast, contextualist approach takes into account the socio-historical context of the Quran as well as the contemporary context of today (Saeed 2006, 3)." Both stances share common ground that the Quran is the revelation of the will of Allah to the Prophet Muhammad, so it must not be considered as human literature that is subject to critiques or arbitral interpretation. Contextualists also admit the significance of the heritage of tafsir or fiqh. However, they emphasize that if one accepts the Quran literally without any consideration of context of the period and place its relevance in our modern society is quite limited or even can be negative. Their challenge to the traditionalist (textualist) Muslim community has opened the possibility to think about religious pluralism in Islamic theology. Contextualists such as Fazlur Rahman, Abdullah Saeed, Farid Esack and Nasr Abu Zayd are generally known as progressive or liberal Muslim thinkers. While they share same principle of interpretation of the Quran each of them has slightly different perspectives in particular emphasis on specific matters. ${ }^{12}$

In a broad sense, most pluralist Muslim scholars agree to the significance of context in interpreting the Quran. They share common idea that the Quran is not an abstract dogma or doctrine but it is God's response to human reality and concrete answers to specific problems in the particular context. It is 'living phenomenon' and

11 Cited in Farid Esack, Quran, Liberation \& Pluralism (Oxford: Oneworld Publications, 1997), 53.

12 Fazlur Rahman, Islam and Modernity: Transformation of an Intellectual Tradition (Chicago and London: University of Chicago Press, 1982); Abdullah Saeed, Interpreting the Quran: Towards a Contemporary Approach (Oxon: Routledge, 2006); Esack, Quran, Liberation \& Pluralism; Nasr Abu Zayd, "Rethinking the Quran: Towards a Humanistic Hermeneutics" (Human Rights and Renewing of Religious Discourse: How Can the Arab World benefit from the Experiences of the nonArab Islamic World?, Alexandria, April 18, 2005). 
should be continuously re-interpreted according to the change of socio-historical context. It is true that their emphasis on the context is different with each other. The key to interpret the Quran adequately might be faith, active engagement for social justice, or understanding it as discourse. But what is still common in their argumentation is that they all firmly believe the Quran as God's revelation and must not be altered.

Their main concern is how they can accommodate the truths of the Quran in modern contemporary society without changing the Author's intention. For all of them the concept of the unity of God and the Prophet Muhammad as a receiver of God's verbatim utterance is undoubtedly true and non-negotiable. They do not try to do 'Copernican Revolution' like a Christian pluralist theologian John Hick who radically changed the concept of salvation, God (the Real in his term) and mythological interpretation. In their argumentation, contextualist scholars are only concerned about horizontal relationship with others including people of different beliefs and have inclusive attitude.

Contextual understanding of the Quran admits that getting along with non-Muslims (togetherness) is good deeds worthy of being praised by God. Muslims can cooperate with those who fight against social injustice and inter-faith dialogue is encouraged for common purpose. The topic of dialogue might be solidarity and cooperation for helping the oppressed and marginalized, facilitating humanistic circumstances in the society and so on. But the dialogue, even though it is inter-religious, is limited in non-theological issues. With regard to conflicting truth claims, there is no room for negotiation or common effort to find transcendental truth satisfying both religious doctrines. In this sense, religious pluralism advocated by John Hick is hardly acceptable for contextualist Muslims.

2. Sociological Perspectives

In the field of sociology of religion, the concept of religious pluralism is complicated and problematic. Beckford analyzes the use of the term among sociologists in three categories. ${ }^{13}$ First, religious pluralism refers to religious diversity. Though in a limited sense, the extent of religious diversity might be an indicator that shows the level of freedom of religion and the circumstances of religious life in a

${ }^{13}$ James A. Beckford, Social Theory and Religion (Cambridge: Cambridge University Press, 2003), 73-81. 
country. Scholars who use the term in this category still have various meaning by it. Pluralism may refer to the number of "separate religious organizations", the number of "distinct faith traditions", or the number of individuals who "combine different religious outlooks". Sometimes diversity means "a formerly unitary religion undergoes a process of internal differentiation." 14

Second, pluralism is about public acceptance or recognition of diverse religions. Societies vary "in respect of the extent to which different religions and religious groups are recognized as legitimate actors in the public sphere. In Beckford's analysis, this acceptability and recognition have several dimensions. First, it is about the scale of formal recognition of religious diversity by the state, asserting that each religion should be respected and protected by legal and constitutional guarantees. Second, it can be about social acceptance, when religious figures or groups function as normal agents in secular affairs. At this level, religious pluralism also refers to the willingness of recognized religious groups to "accept others as worthy partners or competitors in the public sphere." 15 Third, religious pluralism refers to the positive evaluation among citizens that religious diversity and harmonious coexistence in their society are both desirable and achievable.

\section{Religious Pluralism Discourse in the Public Sphere of Indonesia}

Though there is general consensus about the urgency of interreligious harmony, there are still various perspectives and arguments on the actual practices and policies of dealing with religious diversity. This discourse includes, (1) theological debate on the interpretation of the sacred text regarding truth claims and attitude toward people of other faiths; (2) political deliberation about the acceptance or recognition of minor religious groups and institutional guarantee for the freedom of religion; (3) discussion and debate the possibility of inter-religious dialogue and cooperation for the welfare of citizens and for creating peaceful circumstance of coexistence and so on. I would like to call this religious pluralism discourse.

The term "religious pluralism" in Indonesia has been actually, within the environment where the promotion of inter-religious relation or conflicts has overwhelming influence on their lives,

\footnotetext{
14 Beckford, 74-75.

15 Beckford, 77.
} 
understood in widely different meanings. It is not a simply descriptive expression of diversity in religion but ideological or evaluative term to accept or oppose such diversity. (Religious) pluralism was declared as haram by MUI's fatwa in 2005, since it is a deviant theological stance that claims all religions are same. For MUI this term was identical with (theological) relativism. They oppose pluralism in the sense that it undermines Islam's orthodox truths. On the other hand, for pluralist (Christian) theologians religious pluralism means a humble and open-minded attitude toward religious truths that overcomes narrow exclusiveness of each religion and supports the validity of inter-religious dialogue and cooperation. Some others use this term as identical with tolerance and religious freedom. NGO activists also use the term as one of core values of democracy, demanding government's official recognition and institutional protection for religious minorities. There are people who regard religious pluralism as a concept that expresses the particularity of religious and cultural traditions of Indonesia.

Religious pluralism discourse in Indonesia is not a sheer theological debate on the concept of the term but rather a kind of strategic action in political struggle among various groups which have different (religious or political) goals and interests. MUI's fatwa in 2005 that declared pluralism as identical with relativism is probably the case. In the fatwa it is apparently stated that MUI positively support and encourage harmonious social relationship and peaceful coexistence with non-Muslim neighbors. But the reason why they mention pluralism as relativism is probably to counter against liberal pluralism discourse mainly initiated by liberal Islamic organizations such as ICIP, JIL and the Wahid institute and so on.

The fatwa might intend to give alarm to those liberals and urge Indonesian Muslims to strictly stick to orthodox interpretation, especially the exclusiveness of truth in the Quran. ${ }^{16}$ There are also opposite cases. Activities such as official statements, publication, educational programs, inter-religious dialogue, and cultural events for inter-religious encounter and cooperation for social welfare carried out by NGOs are firstly aiming at resolving conflicts and promoting

16 Martin van Bruinessen, "Introduction: Contemporary Developments in Indonesian Islam and the 'Conservative Turn' of the Early Twenty-First Century," in Contemporary Developments in Indonesian Islam: Explaining the "Conservative Turn," ed. Martin van Bruinessen (Singapore: Institute of Southeast Asian Studies, 2013), 3-4. 
mutual understanding. But there are also special purpose to express the value of pluralistic society and the legitimacy of their activities in which various parties of different religious background coexist peacefully through it. It can be regarded as efforts to challenge people's consciousness about the concept of religious pluralism through claiming the validity of it in Indonesian society. These movements are implicitly intended to countering the groups which negatively recognize religious pluralism and oppose it.

\section{Communicative Action Theory and Religious Pluralism Discourse in Indonesia}

This paper looks at how organizations for inter-religious harmony struggle for legitimating their religious pluralism ideas in the society. They make their voices heard by the way of holding conferences and seminars, publishing books, organizing educational program for religious encounter and sometimes doing cultural events and so on in order to convince people that religious pluralism is positive value that should be adopted in the government policies regarding inter-religious relations. How do they struggle in fighting against growing intolerance? What kind of religious pluralism discourse is being developed by those NGOs? How do they legitimize their religious pluralism ideal? (Why do they think their vision of religious pluralism is ideal for Indonesian context?) How do they communicate their ideas with citizens, religious groups and the government?

This paper does not attempt to answer such questions but to suggest a proper theoretical framework to examine those topics. Considering the change after democratization and people's active participation in the religious pluralism discourse, it would be good to examine this phenomenon from the lens of theories on deliberative democracy. More specifically, I suggest the theory of communicative action elaborated by a German philosopher Habermas since those NGOs' have sought inter-faith dialogue and cooperation for mutual understanding, advocate the democratic notion of religious pluralism to the public, and their main method is communication.

a. Theory of Communicative Action

Communicative action refers to the interaction between more than two subjects in order to reach a common understanding about the situation and their plans of action through the process of 
discussion which should be carried out by argument, ground and learning. ${ }^{17}$ In the process of discussion, the common understanding and agreement should be reached through validity claim and its verification by the speakers and hearers. There are three types of validity claims. The agent of action claim "truth for statements or existential presuppositions, rightness for legitimately regulated actions and their normative context, and truthfulness or sincerity for the manifestation of subjective experiences. ${ }^{18}$ The consensus are made in a reflective way, namely their utterances are open to be contested by other actors in a way of interchanging validity claims they reciprocally raise. ${ }^{19}$ Thus, consensus is not merely an agreement, but a recognition and acceptance of the other's proposition as valid after going through deliberation.

In order for the discussion genuinely communicative, several presuppositions are required. Habermas calls them as ideal speech situation: (a) no one who is affected by the discourse should be excluded; (b) all participants have equal right to engage in the discourse; (c) participants must be willing to and able to empathize with each other's validity claims; (d) consensus must be determined only by better argument, not by coercion or deception ${ }^{20}$. "Argumentation insures that all concerned in principle take part, freely and equally, in a cooperative search for truth, where nothing coerces anyone except the force of the better argument." 21 These presuppositions are the bases of Habermas' discourse ethics. He does not intend to provide specific principle or justification but provides a methodological prescription about how moral decisions are to be made. ${ }^{22}$ This kind of action should not be confused with strategically negotiated compromises among conflicting participants.

17 Jürgen Habermas, The Theory of Communicative Action, Volume 1: Reason and the Rationalization of Society, trans. Thomas McCarthy (Boston: Beacon Press, 1981), 86.

18 Habermas, 99.

${ }^{19}$ Habermas, 98-99.

20 Jürgen Habermas, Moral Consciousness and Communicative Action (Cambridge, Mass: MIT Press, 1990), 65-66; Jürgen Habermas, “From Kant's 'Ideas' of Pure Reason to the 'Idealizing' Presuppositions of Communicative Action: Reflections on the Detranscendentalized "Use of Reason," in Pluralism and Pragmatic Turn: The Transformation of Critical Theory, ed. William Rehg and James Bohman (Cambridge, London: The MIT Press, 2001), 34.

${ }^{21}$ Habermas, Moral Consciousness and Communicative Action, 198.

22 Richard Harvey Brown and Douglas Goodman, "Jürgen Habermas' Theory of Communicative Action: An Incomplete Project," in Handbook of Social Theory, ed. 
Strategic action is purposively rational but it lacks the normative justification about the consequences. According to Habermas, the pathologies of modern capitalist society are caused by the increase of influential power of instrumental rationality especially in the market economy and in the bureaucratic sector while communicative rationality developed and operated in the lifeworld has been "colonized" by the system in which instrumental rationality has dominant power. ${ }^{23} \mathrm{He}$ suggests that, in order to remedy the pathologies, people should actualize the communicative action for the purpose of revitalizing the critical nature of the public sphere in which public opinions are formed by citizens' deliberation and become legitimate foundation for legislation.

In the case of inter-religious NGOs, there are some similar structural features with the theory of communicative action. First of all, they are seeking dialogue between people of different interests, beliefs and cultural background. The purpose of dialogue is to understand each other and reach a consensus for ideal vision of community which embraces various groups including religious minorities. In addition, they attempted to challenge conventional discourse on religious pluralism in civil society dominated by mainstream religious organizations and hard-liner groups. It could be viewed as endeavor to contest the validity of hegemonic notion of religious pluralism and to claim the validity of their argumentation. Seemingly it is a good case to show the growth of civil society able to deal with religiously sensitive issues in a more democratic way, namely through deliberation. The theory of communicative action seems to be suitable to analyze the phenomenon. However, some conceptions and presuppositions of this theory need to be critically accessed and modified so that it can be applied to cultural contexts other than in Europe where Habermas focused on.

b. The Problem of Universalized Rationality and Indonesians' Social Imaginaries

Habermas envisages the universalization of rationality which could be achieved only by logical argumentation. The goal of theory

George Ritzer and Barry Smart (London, Thousand Oaks and New Delhi: SAGE Publications, 2003), 207.

${ }^{23}$ Jürgen Habermas, The Theory of Communicative Action, Volume 2: Lifeworld and System: A Critique of Functionalist Reason, trans. Thomas McCarthy (Boston: Beacon Press, 1987). 
of communicative action is that of "clarifying the presuppositions of the rationality of processes of reaching understanding, which may be presumed to be universal because they are unavoidable." ${ }^{24}$ He argues that in the process of reaching understanding, validity claims are 'always already' implicitly raised. This logical procedure is, for him, inherent in human's activity and universally applied to every context. In this frame, in order for the outcome of a consensus to be rational, the parties must mutually verify only through the validity of the claim, excluding any background, condition, or external forces. However, this condition is too idealistic and normative, and involves many problems.

First, the question is raised whether people's ideas and arguments can be formulated without any influence of their background such as religion, tradition, natural environment and so on. Logical argumentation cannot be started from zero. Our thought of morality, value, priority and the notion of right and wrong and so on are actually the product of our cultural circumstances and thus the standards of rationality are also shaped in various ways in accordance with our cultural contexts.

Although Habermas emphasized the universality of procedural character of rationality in his theory, not substantive rationality, the procedure itself is also the object to be influenced by such different contexts. Especially in political decision making people have to consider conflicting values, priorities and interests of various groups and individuals. Rather than resorting to logical validity claims, we often use compromising and yielding to reach a consensus in order to avoid the worst outcome, not the best one. And in this process people's religious, ethnic, environmental background functions as the criteria for deciding which is rational and which is not. It is not considered as irregular, far from ideal situation, but the reality of political life. Habermas' assertion that all external influences should be excluded and that consensus is reached only through mutual exchange of validity claims is empirically unrealistic and it is not necessarily normatively desirable.

Second, the universalization assumption of rationality is more problematic when the parties to the discussion have different cognitive bases. Is it possible to "reach" mutual understanding

24 Jürgen Habermas, "Questions and Counterquestions," in Habermas and Modernity, ed. Richard J. Bernstein (Cambridge, Mass: MIT Press, 1985), 196. 
without taking into account the specific background of the other's family background, religious, ideological beliefs, race, language, etc.? Can we be sure that we understand exactly what our counterpart of discussion intended? Hans Gadamer says that such an understanding is impossible. According to Gadamer, there is no truth that is not grounded in human history, and human beings can never leave their own "historical horizon." Our thought is a product of our history including education, assumption of our prejudices, parents, culture, and so on. There is no universal rationality that is not subject to a historical process of change. ${ }^{25}$

The importance of inter-religious dialogue is not to reach some neutral stance which is untouched by our beliefs and prejudices. For Gadamer, our prejudices are the precondition of thought. Understanding others means that we "transpose ourselves" into other people's situation. Common understanding happens not only through logical argumentation but also through "fusion of horizons." Therefore, we are not sure whether we really "reach common understanding" only by verifying validity claims because our horizon of consciousness may be different from that of others. However, it is not to claim that all truths are relative. It means that we cannot deny the existence of our prejudices and that rationality should also be considered in the cultural and historical context.

The limitation of his theory in this sense is very clear in analyzing societies like Indonesia which has a very different historical experience and social structure from Western capitalist countries. It is obvious that Indonesia is also under the influence of modernization, and the influence from outside world is increasing as globalization continues. However, Indonesia has developed its unique tradition and maintained strong religiosity even in the globalization process. Indonesia has unique social imaginaries substantially different from those of Western societies. ${ }^{26}$

\footnotetext{
${ }^{25}$ Hans-Georg Gadamer, Truth and Method, second edition (London and New York: Continuum, 1989), 303-6.

26 Social imaginary is "the ways people imagine their social existence, how they fit together with others, how things go on between them and their fellows." It is, maybe different more or less between persons, "imagined" reality of the society by "ordinary" people. People recognize it through "images, stories and legends." Such common understanding enables us to do "collective practices that make up our social life" and gives "a widely shared sense of legitimacy." And also, it includes
} 
The Western dichotomy between rationality and irrationality, concept of equality and evolutionary view on history and so on are very foreign to most Indonesians who imagine their society as inner/outer world, hierarchical status of individuals and the repetition of history. Even though Indonesians highly value Western, modern concept of rationality and its application in the social system, their social actions are still strongly influenced by their traditional and religious worldview and philosophy which is seemingly contradictory from the perspective of Westerners. ${ }^{27}$

Therefore, in applying theory of communicative action, the concept of communicative rationality should not be taken for granted as universalized standard, but should be more culturally contextualized, taking religion, ethnicity, language, traditions and etc., into consideration in discourses in the public sphere. Actually Habermas opened the possibility of this flexibility in his conception of intersubjectivity. Whether a certain social action is rational or not is determined by the consensus between the participants of the debate according to Habermas' theory. Intersubjectivity makes it possible to find Indonesia's unique way of reaching agreement when we observe what kind of validity claims are used or emphasized in justifying their religious pluralism ideas and social activities. It would be also interesting to compare the agreed results gained through such communication with those of similar cases in Western world.

c. The Problem of Power Relation and Strategic Action

Another thing to think about in connection with the first question is the power relation between the parties. Habermas supposes an ideal type which he calls "ideal speech situation" in which all external forces like religions, traditions, customs, and authority from relationships are excluded and only better arguments can act as a legitimate force in the discussion. This premise has some problems with regard to power relations between the participants of discussion.

First, it is virtually impossible to reach consensus based purely on logical validity excluding the power relation between participants

normative aspects such as the question of "how the things ought to go." Taylor, 23-24.

27 Bernard Adeney-Risakotta, "Indonesian and Western Social Imaginaries," in Dealing with Diversity: Religion, Globalization, Violence, Gender and Disaster in Indonesia, ed. Bernard Adeney-Risakotta (Geneva: Globethics.net, 2014), 91-130. 
especially in a discussion for political decision-making. The parties to the discussion are either consciously or unconsciously influenced by the existing power relations between the parties. Discussions in the public sphere are not a joint effort to discover pure facts, but rather a reality in which each one brings their own interests and competes and contends using every means. Almost everything about freedom and equality, including freedom to participate in discussions, freedom to speak according to conscience, as well as the right to access necessary information for fair discussion, to set an agenda for debate are influenced by the power of the participants.

According to Foucault, all relations are regulated by power relations, and the criteria of rationality in a certain age or society are largely determined by the relationship of these powers. He argues that there was no linear, evolutionary development on human rationality in history, but the criteria for rationality have been significantly different in different times, depending on who has power and what interests they hold. Over simply speaking, what is true and rational is determined by power. ${ }^{28}$ In considering this reality, power vacuum situation that literally fully guarantees free and equal condition for discussion is far from reality. Therefore, it is inevitable to revise the assumption of the theory of communicative action, that is, reaching consensus only through validity claims in power vacuum 'free and equal' condition.

Any strategic actions to challenge dominant power in order to create free and equal conditions for discussion should also be considered as legitimately rational action for the progress of democracy. For example, in a relationship where power relations are significantly unbalanced, efforts to change the balance are also very important for establishing free and equal condition of discussion. In addition, if the goal of any participant is morally and normatively correct, the various rationales for reaching the goal, such as negotiation, rhetoric, and group behavior, can be evaluated differently on a case by case basis.

d. The Legitimacy of Religious Reason in Public Discourse

This is also related to the controversy over the concept of universal rationality. There is much controversy as to whether religious reason can be grounds for plausibility in public discourse.

28 Michel Foucault, Power/Knowledge: Selected Interviews and Other Writings 1972-1977, ed. Colin Gordon (New York: Pantheon Books, 1980). 
Habermas basically grasps history from an evolutionary point of view, and as society progressively rationalizes, people are freed to questioning about the legitimacy of existing traditions, religious authorities, customs, and norms, and so on. Early Habermas supported the secularist theory that the influence of religion would gradually decline in the process of rationalization of society, and that the religious reason should be excluded from public discourse.

According to his earlier position, religious reason is in the realm of faith and can be used as an argument for discussion only to those belonging to the same community of faith, but it is not universal when discussing it with people of other cognitive backgrounds in public discourse. His view of religious reason has changed over time. He gradually recognizes the contribution of religious reason in the public sphere, especially in giving meaning of life, aspiration for the advance of justice etc. But he still holds the position that religious reason should be translated by secular language so that other secular citizens can understand, and that the other secular citizens should also be committed to trying to understand the claims of other citizens based on religious reason. ${ }^{29}$ Although Habermas' view of the religious reason is much more advanced than his earlier position, he still holds that religious reason has limited legitimacy in public discourse. ${ }^{30}$

There are many critics on Habermas' view on religion. First, even though political argument based on religious conviction has different cognitive basis from the logic of secular citizens they could reach agreement. It is not because secular citizens accept religious citizens' belief but because they accept the argument as rational after investigating it with their own rational basis. For example, when religious people claim to prohibit murder and theft on the basis of what they believe, secular citizens agree to the claim but are not obliged to agree to their beliefs. In other words, even if religious citizens speak in the language of religion, secular citizens accept what is acceptable in their validity criteria and refute what is not. The agreement is not only from logical validity but also from shared experience. "This kind of agreement does not violate the neutrality principle since the basis of agreement lies in a shared world and

29 Jürgen Habermas, "Religion in the Public Sphere," European Journal of Philosophy 14, no. 1 (2006): 1-25.

30 William J. Meyer, "Private Faith or Public Religoin? An Assessment of Habermas's Changing View of Religion," The Journal of Religion 75, no. 3 (1995): 372-81. 
Religious Pluralism Discourse in Public Sphere of Indonesia: A Critical Application of Communicative Action Theory to Inter-Religious Dialogue

common activities that remain independent of particular commitments. ${ }^{31}$

Second, given that the religious people are based on religious reason for the validity of their claim, it is free to try to translate it, but it is not an obligation. If the public sphere is open to anyone freely and open to criticism, the freedom to bring religious reason as the basis for validity claims must be guaranteed, it could rather be an opportunity of expanding our horizon of knowledge through experiencing different cognitively based discussion. If the agreement is reached, reflexivity of rationality can still be maintained even if the parties to the debate have a different cognitive basis.

Third, religion seeks to "speak validity about the whole of existence." ${ }^{32}$ In addition to the three spheres of validity, that is objective truth, moral rightness and subjective truthfulness, religion has its own validity sphere which integrate all the other validity spheres. It is true that modern rationality structure has experienced the differentiation and expert culture has developed correspondingly connected to each sphere of rationality, but there is still need of integration of rationality which still preserve the differentiation. Religious reason gives such function in modern society.

\section{Conclusion}

Habermas presents this concept communicative rationality as a concept of universal rationality which is not limited to a specific region but applicable to all societies. However, as already mentioned, his theory makes a mistake in sacrificing the pluralistic character or the contextual specificity of rationality in trying to generalize the concept of rationality. If we are inclined to Habermas' theory too much, we can fall into the precipitous generalization error of evaluating the appearance of social change in various societies in various ways only on the basis of the development of rationality. It is more convincing that investigating the validity claim can only be established on the basis of certain cultural backgrounds and convictions shared by the members of the society.

\footnotetext{
31 Phil Enns, "Habermas, Democracy and Religious Reasons," The Heythrop Journal, $2010,585$.

32 Meyer, "Private Faith or Public Religoin? An Assessment of Habermas's Changing View of Religion," 378.
} 
When we recognize that we have "prejudice," that is, recognizing the cultural specificity of our own society and participating discussion with others based on it, a "fusion of horizon" will arise and we would discover a more comprehensive and diverse development of rationality. I do not claim that there is no universal standard for rationality. I rather argue that Habermas' concept of rationality requires cultural contextualization so that it can be applied to more societies.

Another problem derived from the question of universality is the validity of religious reason. Habermas shows that religious reason is difficult to be justified in the public realm because of its lack of reflexivity and lack of differentiation. His view of religion has changed quite positively in the latter days, but he is still skeptical of the public role of religious reason. But if one accepts religious beliefs as one of the various background convictions we share in a culture, such religious reasoning can be presented as a basis for rationality in public debate. It is also true that, as a result of differentiation, the three aspects of rationality have developed greatly in modern society, but we still have desire for an understanding of the real world as a whole, for which the metaphysical or religious realm has a qualitative validity. It should be acknowledged as the forth sphere of validity claim.

Despite its weaknesses, Habermas' theory of communicative action theory still provides a useful framework for understanding modern society. In order to analyze the discourse of religious pluralism in Indonesian civil society, the concept of rationality of Habermas which has been modified by the consideration mentioned above will be useful lens for understanding Indonesian society. This study does not seek to establish the absolute and universal standard of rationality and to measure the degree of rationality development in Indonesia, but to interpret how rationality structure of Indonesian civil society is formed in the culture, assuming multicultural aspects of rationality. Indonesian case will be the basis for the "fusion of horizon" to broaden our knowledge of other cultures. In the light of the above-mentioned criticisms, I will now make some modification of the assumptions of Habermas' theory of communicative action and so that it can be effectively applicable to the case of Indonesia's religious pluralism discourse. 
First, in contrast to strategic rationality, communicative action is the rationality by which individuals or group recognize common good and coordinate different interests of each other to reach consensus. In order to overcome the "colonization of the lifeworld" and to solve the pathologies of modern society, it is necessary to restore rationality based on communicative action. It appears as a process in which citizens actively take part in discourses on social issues in public sphere, draw consensus and form public opinion through discursive debate, and demand the State reflect their public opinion through legislation and institutionalization. The more active the discussion and consensus in the public sphere, the more laws and regulations reflect the consensus of citizens, and the stronger is the legitimacy of state power. The solidarity of its members in the society is also strengthened.

Second, communicative rationality is not established solely by logical argumentation in a vacuum that removes all cultural backgrounds or power relation. Rational debate should be substantively based on the cultural background and common convictions shared by the members of the society. Furthermore, we should recognize the power relation between the participants of discussion which influence and consensus drawn through the discussion is reproduced as a cultural resource in the lifeworld.

Third, religious reason and metaphysical thought can be used as a basis for validity in the area of public debate in the process of social rationalization. The domain of metaphysical validity should be included as legitimate aspect of validity claim as well as the three other aspects of rationality proposed by Habermas. In other words, people can present public opinion based on their religious beliefs in the public sphere and use it as a basis for validity claims for their opinions. We need to investigate whether the logic is widely recognized as a reasonable idea within the religion of the speaker, and if necessary, to translate it into secular language so that people of different religion or other secular citizen can understand the argument. In other words, it means that anyone has the right to present his or her religious beliefs as a basis of the argument in public debate. One's religious conviction is to be treated as legitimate source of public discussion. 


\section{Bibliography}

Adeney-Risakotta, Bernard. "Indonesian and Western Social Imaginaries." In Dealing with Diversity: Religion, Globalization, Violence, Gender and Disaster in Indonesia, edited by Bernard Adeney-Risakotta, 91-130. Geneva: Globethics.net, 2014.

. Living in a Sacred Cosmos: Indonesia and the Future of Islam. New Haven, CT: Yale Univ Southeast Asia Studies, 2018.

Arifianto, Alexander R. "Explaining the Cause of Muslim-Christian Conflicts in Indonesia: Tracing the Origins of Kristenisasi and Islamisasi." Islam and Christian-Muslim Relations 20, no. 1 (2009).

Beckford, James A. Social Theory and Religion. Cambridge: Cambridge University Press, 2003.

Bertrand, Jacques. Nationalism and Ethnic Conflict in Indonesia. Cambridge; New York: Cambridge University Press, 2004.

Boase, Roger. Islam and Global Dialogue: Religious Pluralism and the Pursuit of Peace. Burlington: Ashgate, 2005.

Bruinessen, Martin van (ed.). Contemporary Developments in Indonesian Islam: Explaining the "Conservative Turn." Singapore: Institute of Southeast Asian Studies, 2013.

CRCS. Laporan Tahunan Kebidupan Beragama di Indonesia Tahun 2008. Yogyakarta: Center for Religious and Cross-cultural Studies, 2008.

Enns, Phil. "Habermas, Democracy and Religious Reasons." The Heythrop Journal, (2010).

Esack, Farid. Quran, Liberation \& Pluralism. Oxford: Oneworld Publications, 1997.

Fernandes, Clinton, and Damien Kingsbury. "Terrorism in Archipelagic Southeast Asia," in Damien Kingsbury (ed.). Violence in between: Conflict and Security in Archipelagic Southeast Asia. Singapore: Monash University Press and ISEAS Publications, 2005.

Foucault, Michel. Power/Knowledge: Selected Interviews and Other Writings 1972-1977. Edited by Colin Gordon. New York: Pantheon Books, 1980.

Gadamer, Hans-Georg. Truth and Method. Second edition. London and New York: Continuum, 1989.

Habermas, Jürgen. 'From Kant's 'Ideas' of Pure Reason to the 'Idealizing' Presuppositions of Communicative Action: Reflections on the Detranscendentalized 'Use of Reason."' In 
Pluralism and Pragmatic Turn: The Transformation of Critical Theory, edited by William Rehg and James Bohman, 11-39. Cambridge, London: The MIT Press, 2001.

- Moral Consciousness and Communicative Action. Cambridge, Mass: MIT Press, 1990.

- "Questions and Counterquestions." In Habermas and Modernity, edited by Richard J. Bernstein, 192-216. Cambridge, Mass: MIT Press, 1985.

. "Religion in the Public Sphere." European Journal of Philosophy 14, no. 1 (2006): 1-25.

- The Theory of Communicative Action, Volume 1: Reason and the Rationalization of Society. Translated by Thomas McCarthy. Boston: Beacon Press, 1981.

- The Theory of Communicative Action, Volume 2: Lifeworld and System: A Critique of Functionalist Reason. Translated by Thomas McCarthy. Boston: Beacon Press, 1987.

Hasan, Noorhaidi. "Post-Islamist Politics in Indonesia." In PostIslamism:The Changing Faces of Political Islam, edited by Asef Bayat, 157-84. New York: Oxford University Press, 2013.

Hick, John. An Interpretation of Religion: Human Responses to the Transcendent. New Haven: Yale University Press, 1989.

Knitter, Paul F. "Introduction." In The Myth of Religious Superiority: Multi-Faith Explorations of Religious Pluralism, edited by Paul F. Knitter, vii-xi. New York: Orbis Books, 2005.

-. "Is the Pluralist Model a Western Imposition?: A Response in Five Voices." In The Myth of Religious Superiority: Multi-Faith Explorations of Religious Pluralism, edited by Paul F. Knitter, 2844. New York: Orbis Books, 2005.

Menchik, Jeremy. Islam and Democracy in Indonesia: Tolerance without Liberalism. Cambridge: Cambridge University Press, 2016.

Meyer, William J. "Private Faith or Public Religoin? An Assessment of Habermas's Changing View of Religion." The Journal of Religion 75, no. 3 (1995).

Mujīburraḥmān. Feeling Threatened: Muslim-Christian Relations in Indonesia's New Order. Amsterdam: Amsterdam University Press, 2006.

Rahman, Fazlur. Islam and Modernity: Transformation of an Intellectual Tradition. Chicago and London: University of Chicago Press, 1982. 
Ritzer, George and Smart, Barry (eds.). Handbook of Social Theory. London: SAGE Publications, 2003.

Saeed, Abdullah. Interpreting the Quran: Towards a Contemporary Approach. Oxon: Routledge, 2006.

Taylor, Charles. Modern Social Imaginaries. Durham: Duke University Press Books, 2003.

Zayd, Nasr Abu. "Rethinking the Quran: Towards a Humanistic Hermeneutics." Presented at the Human Rights and Renewing of Religious Discourse: How Can the Arab World benefit from the Experiences of the non-Arab Islamic World?. Alexandria, April 18, 2005. 